\title{
Relationships among Perceptual Learning Style, the Ideal L2 Self, and Motivated L2 Behavior in College Language Learners
}

\author{
TAE-Young KIM \\ Chung-Ang University, Korea \\ Miso KIM \\ The Pennsylvania State University
}

Received: 14 April 2015 / Accepted 21 August 2017

ISSN: $1697-7467$

\begin{abstract}
The study investigated the effects of 283 college students' perceptual learning styles, imagination, and the ideal L2 self on their motivated L2 behavior. The college students were found to prefer a visual learning style the most, followed by auditory and kinesthetic styles. Statistical analyses indicated that visual and auditory styles were meaningfully correlated with motivated behavior, while the kinesthetic style was not; this was consistent with the findings of younger students. Sequential regression analysis found that the ideal L2 self had the most explanatory power, followed by imagination, auditory style, and visual style. No statistically significant difference was found between male and female students in the perceptual learning style variables.
\end{abstract}

Keywords: Perceptual Learning Style, L2 Motivational Self System, Ideal L2 Self, Motivated Behavior, Imagination.

Relaciones entre el Estilo de aprendizaje perceptual, el Ideal de uno mismo en L2 y el Comportamiento motivado en L2 en estudiantes universitarios de idiomas

RESUMEN: El estudio investigó los efectos que tienen los estilos de aprendizaje perceptuales, la imaginación y el ideal de uno mismo en L2 sobre el comportamiento motivado en L2 de 283 estudiantes universitarios. Los estudiantes prefieren mayoritariamente un estilo de aprendizaje visual, seguido por estilos auditivos y quinestésicos. Los análisis estadísticos indican que los estilos visuales y auditivos estaban significativamente relacionados con el comportamiento motivado, mientras que el estilo quinestésico no; esto fue similar a los resultados de estudiantes más jóvenes. El análisis de regresión secuencial reveló que el ideal de uno mismo en L2 tuvo el poder más explicativo, seguido por la imaginación, el estilo auditivo y el estilo visual. La diferencia de género no fue encontrada dentro de las variables.

Palabras clave: Estilo de aprendizaje perceptual, autosistema motivacional en L2, Ideal de uno mismo en L2, comportamiento motivado, imaginación. 


\section{INTRODUCTION}

This paper examines the perceptual learning styles and the ideal second language (L2) self of South Korean college students learning English as a foreign language, and their effects on the students' motivated L2 behavior. ${ }^{1}$ The ideal L2 self, proposed by Dörnyei (2005, 2009), represents learners' L2-related dreams, hopes, and desired self-image(s). Students are motivated to learn English by becoming aware of and desiring to close the gap between their ideal L2 self and their current state. Dörnyei (2009) emphasizes the beneficial role of L2 learners' visual imagery in creating a vivid ideal L2 self and boosting motivation. The visual imagery is connected to recent discussion of "belonging through imagination" (Wenger, 1998), where imagination is "not just the production of personal fantasies. Far from an individual withdrawal from reality, it is a mode of belonging that always involves the social world to expand the scope of reality" (p. 178). Therefore, in L2 learning situations, the learners' sense of belonging to L2-speaking communities by creating vivid mental imagery plays a key role in motivation.

The question taken up here on the basis of Dörnyei's insight is, does the capacity for imagery and imagination lead to a stronger ideal L2 self and a higher degree of L2 learning motivation? Al-Shehri (2009) first raised this question, investigating the relationship between college-bound Saudi Arabian high school graduates' visual learning style and the ideal L2 self under the principle that visual-style learners are "likely to exhibit a strong capacity for imagery and imagination" (p. 164). Kim (2009) further elaborated on Al-Shehri's (2009) study on perceptual styles; referring to Dörnyei's (2005) argument that successful L2 learners use both visual and auditory input, Kim (2009) suggested that other perceptual styles may also have an effect on the ideal L2 self and motivated L2 behavior. Referring to Reid's (1987) classification of perceptual learning styles, Kim (2009), Kim and Kim (2011a), and Kim and Kim (2014) investigated three perceptual learning styles (i.e., visual, auditory, and kinesthetic) and their relationships with the ideal L2 self and motivated L2 behavior. The results of these studies indicated that both visual and auditory styles were predictors of motivated L2 behavior among both elementary and secondary school students.

Given this background, this study aims to investigate college-level students majoring in English linguistics and literature or in English-language education. College students face a largely different learning context from elementary or secondary students. In Korean elementary schools, English is taught 2-3 hours a week in public schools (Ministry of Education, Science and Technology of the Republic of Korea, 2009), with a focus on developing basic English skills for everyday life (Ministry of Education, Science and Technology, 2011). In Korean secondary schools, the major motivation for high school students to study English is to gain admission to a prestigious university in Korea (Kim, 2006, 2010, 2017; Seth, 2002). To achieve this goal, they are expected to take English classes for a designated amount of time, as specified in the national English curriculum. Although a series of attempts have been made to improve public English education, English classrooms in high schools remain exam oriented (Bang \& Chun, 2011; S.-A. Kim, 2006). In contrast, Korean college students have

\footnotetext{
${ }^{1}$ In this paper, both second language and foreign language will be referred to as "L2."
} 
already chosen a major, indicating a voluntary intention to study further, and they continue to choose their own classes in their areas of interest. They may choose English-related majors to achieve English-related goals, such as becoming a translator or an English teacher.

Based on the awareness of this contextual difference, this study will extend the investigations conducted by previous studies on perceptual learning style and the ideal L2 self (AlShehri, 2009; Dörnyei \& Chan, 2013; Kim, 2009; Kim \& Kim, 2011a, 2011b) in a population of Korean-speaking English as a foreign language (EFL) learners at the college level and compare them to results for elementary and secondary school students in English classes.

\section{Literature REVIEW}

Motivation to learn a new language has long been studied within the framework of Gardner's $(1985,2001)$ socio-educational model. First suggested by Gardner and Lambert (1959), the model was developed in a unique Canadian bilingual context, where students were learning French as a second language. The model included two key concepts: integrativeness and instrumentality. Integrativeness "reflects a genuine interest in learning the second language in order to come closer to the other language community" (Gardner, 2001, p. 5). In other words, the desire to be integrated into the society of speakers of the target language facilitates the motivation to learn the target language. In contrast, instrumentality reflects the desire to learn a language for utilitarian purposes, such as getting a good score on a university entrance exam or securing a job. The socio-educational model focused on the social psychological aspects of motivation (Ushioda, 2010), using psychometric methods to collect and analyze data.

Since the 1990s, various questions and criticism of the socio-educational model have been raised. Crookes and Schmidt (1991) pointed out that the results of empirical research using the model were mixed and inconsistent and that the model does not adequately reflect L2 teachers' practical concern about how to increase their students' low level of motivation. In addition, the concept of integrativeness does not take EFL context into account-specifically, does not adequately reflect cases where the target community to be integrated into is not physically present (Oxford \& Shearin, 1994). Moreover, the exact characteristics and boundaries of this target language community can be vague, particularly due to globalisation and the accompanying status of English as an international lingua franca (Dörnyei, 2009; McKay, 2002).

Given these increasing criticisms of Gardner's concept of integrativeness at least in the context of the teaching of English, Dörnyei (2005, 2009) proposed the L2 motivational self system, inspired by psychological concepts from Markus and Nurius (1986) and Higgins (1987). Markus and Nurius (1986) suggested that possible selves 'represent individuals' idea of what they might become, what they would like to become, and what they are afraid of becoming" (p. 954). Going a step further, Higgins (1987) used the terms actual self, ideal self, and ought self. The gap between actual self and ideal and ought selves gives rise to self-guides, internalised standards that generate motivation if they are personally relevant to the learner. In Higgins's (1987) words, "we are motivated to reach a condition where our self-concept matches our personally relevant self-guides" (p. 321). 
Dörnyei (2005) first applied these insights to L2 motivation research to develop the L2 motivational self system. The system is composed of three components: (1) the ideal L2 self, a learners' self-image of what he or she would like to become using the L2; (2) the oughtto L2 self, the attributes that the learner has to acquire in order to meet expectations from others and avoid negative consequences; and (3) L2 learning experience, which covers not only learning experience and exposure to particular learning environment but also motives rooted in these constructs (Dörnyei, 2005, 2009). Dörnyei pays special attention to the role of the ideal L2 self, which is "a powerful motivator to learn the L2 because of the desire to reduce the discrepancy between our actual and ideal selves" (2009, p. 29). In creating and strengthening the ideal L2 self, the role of vivid imagery is crucial. Dörnyei (2009) referred to research on imagery enhancement and image training of athletes (e.g., Berkovits, 2005; Gould, Damarijian, \& Greenleaf, 2002), which are "designed to enhance the vividness and controllability of an athlete's imagery" (p. 35). By citing the studies, Dörnyei argues that conscious use of mental imagery, or "the ability to represent perceptual states in the absence of the appropriate sensory input" (p. 16), will lead to increased L2 motivation and the clear vision of mastering a foreign language.

Previous studies have provided empirical support for Dörnyei's model. For example, Taguchi, Magid, and Papi (2009) found that the concept of integrativeness in Gardner's model can be reinterpreted in terms of the ideal L2 self, which they found to have better explanatory power than integrativeness when employed in structural equation modeling of L2 learning motivation among Chinese, Japanese, and Iranian learners of English. Magid (2012) and Papi (2010) also found that the ideal L2 self had explanatory power for L2 learning motivation. In the Korean context, the ideal L2 self has been found to be a strong predictor of students' motivated L2 behavior (Kim, 2009, 2012; Kim \& Kim, 2011a, 2011b; Park \& Lee, 2013; Yang \& Kim, 2011), and a cross-grade survey analysis of Grade 3 to 12 students revealed that the L2 motivational self system was a better predictor than the socio-educational model (Kim, 2012).

It has been proven that students preferring visual learning styles learn better if visual materials, such as charts, diagrams, and pictures, are used for instruction, and kinesthetic learners learn better if they are physically involved with learning activities (Reid, 1987). In the same collection of papers in which Dörnyei (2009) emphasized the role of imagery in creating and substantiating the ideal L2 self, Al-Shehri (2009) raised the question, rooted in Dörnyei's findings, of whether learners with visual learning styles may have a stronger ideal L2 self. His research has shown that Saudi Arabian high school graduates have strong visual memory and prefer modeling to explanation. Given the characteristics of visual style preferences, the study examined correlations between the ideal L2 self, visual style, and imagery capacity among Saudi Arabian students' learning English. The results indicated that visual style, imagery capacity, and motivation were all positively correlated, and that visual style and imagery capacity together explained $47 \%$ of the variance in the ideal L2 self. The argument that vivid imagery leads to increased motivation and higher L2 proficiency is supported by You and Chan's (2015) exploratory mixed-method study. Moreover, You, Dörnyei, and Csizér (2016) integrated variables on imagery in the central element of L2 learning motivation. 
Tae-Young Kim And Miso Kim Relationships among Perceptual Learning Style, the Ideal L2 Self ...

However, as Kim (2009) has pointed out, "given the nature of language learning and teaching, the postulation that only the visual learning style is related to the ideal L2 self and the maintenance of L2 learning motivation remains controversial" (p. 462). Learning a new language, after all, also means learning verbal communication skills. Given this, Kim's study investigated the relationship between three major perceptual learning styles (visual, auditory, and kinesthetic), motivated L2 behavior, imagination, and the ideal L2 self among 974 Korean elementary school students. The results indicated that visual and auditory style preferences were positively correlated with imagination and the ideal L2 self, both of which were predictors of motivated L2 behavior. In contrast, the kinesthetic style preference was found to be negatively correlated with the ideal L2 self and therefore to exert a negative effect on motivated behavior. Similar results have also been found among secondary students by Kim and Kim's (2011a, 2011b). In a related finding among Chinese and Japanese learners of English, kinesthetic style had no significant relationship with self-guides (Yang \& Kim, 2011). Dörnyei and Chan's (2013) recent study conducted in Hong Kong also found that both visual and auditory learning styles of 172 Chinese secondary school students were significantly correlated with the ideal L2 self.

Whereas these previous studies examined elementary students (Kim, 2009) and secondary students (Dörnyei \& Chan, 2013; Kim \& Kim, 2011a, 2011b; Yang \& Kim, 2011), this study focuses onadult students majoring in English in college. As noted earlier, college students study English in a more voluntary context than elementary and secondary students, and most of them have specific reasons for choosing an English major. Taking these individual and contextual differences into account, this research focuses on investigating English-major college students' perceptual learning styles, imagination, and the ideal L2 self and comparing the results with previous studies on elementary and secondary students. The research questions are as follows:

1. What are the relationships among three perceptual learning styles (visual, auditory, and kinesthetic), imagination, the ideal L2 self, and motivated L2 behavior?

2. What is the impact, if any, of the three perceptual learning styles, imagination, and the ideal L2 self on motivated L2 behavior?

3. Is there any gender difference in the effects, if any, of the three perceptual learning styles, imagination, and the ideal L2 self on motivated L2 behavior?

\section{RESEARCH METHOD}

\subsection{Participants}

The research used the data collected by Department of English Education at a private university in Seoul. The dataset consisted of questionnaires responded by 283 students in two universities. Of the participants, 108 (38.2\%) were studying English language and literature and $175(61.8 \%)$ were studying English language education; 220 (77.7\%) were female and $63(22.3 \%)$ were male. A total of $190(67.1 \%)$ reported that they had received private English education in addition to their public English education, and 77 (28.2\%) had study-abroad experience in English-speaking countries. 


\subsection{Data collection method}

The questionnaire of the dataset is designed by Kim (2009) and Kim and Kim (2011a, $2011 \mathrm{~b}, 2014)$. The questionnaire composed of two sections: the first section asked the participants' academic major, gender, English test scores in high school, private education experience, and experience living or studying abroad, and the second section measured their perceptual learning style, imagination, the ideal L2 self, and motivated L2 behavior (see Appendix for sample questions). As for the items on perceptual style, Kim (2009) and Kim and Kim (2011a, 2011b, 2014) adopted Cohen, Oxford, and Chi's (2002) Learning Style Survey, and translated them into Korean. The original survey, according to Cohen and Weaver (2005), is drawn from Oxford's (1995) Style Analysis Survey and other related works by Ehrman and Leaver (1997, 2003). As for imagination, Kim (2009) devised the items based on previous research on mental imagery (e.g., Dörnyei, 2005, 2009; Kosslyn et al., 2002; Modell, 2003; Wenger, 1998). Lastly, items for the ideal L2 self and motivated L2 behavior were brought from Al-Shehri's (2009) study. Kim (2009) and Kim and Kim (2011a, 2011b, 2014) translated all items into Korean, piloted the questionnaire, and recalibrated the items based on statistical results. For this study, 6 out of 21 items on perceptual learning style were removed, because the initial Cronbach's alpha indicated these items lowered internal consistency. All questionnaire items were presented in Korean, the participants' L1, and used a five-point Likert-type scale.

\subsection{Data analysis}

The dataset was analyzed using SPSS 18.0. A descriptive analysis was performed to determine the participants' perceptual learning preferences. Next, descriptive statistics for imagination, the ideal L2 self, and motivated L2 behavior were also calculated. Then, Pearson product-moment correlation coefficients were calculated to identify the relationships between the three perceptual learning styles, imagination, the ideal L2 self, and motivated L2 behavior. Sequential regression analysis revealed which variables had explanatory power over motivated L2 behavior. After that, in order to verify gender differences in the perceptual learning styles and the motivational constructs, the Mann-Whitney $U$ test was conducted.

First, however, Cronbach's alpha for each factor was calculated to check internal consistency. Cronbach's alpha indexes were $\alpha=.66$ for visual style, $\alpha=.56$ for auditory style, $\alpha=.59$ for kinesthetic style, $\alpha=.67$ for imagination, $\alpha=.87$ for the ideal L2 self, and $\alpha=.88$ for motivated L2 behavior. While Cronbach's alphas for auditory and kinesthetic styles were lower than other variables, they were higher than 0.5 and thus considered acceptable according to Nunnally (1967) and Davis (1964) (as cited in Peterson [1994]).

\section{Results AND Discussion}

\subsection{College English majors' learning styles and motivational profiles}

First of all, means and standard deviations of the six variables (visual style, auditory style, kinesthetic style, imagination, the ideal L2 self, and motivated L2 behavior) were calculated. A previous study on Korean college students has revealed that on the whole they 
Tae-Young Kim And Miso Kim Relationships among Perceptual Learning Style, the Ideal L2 Self ...

prefer the auditory style to visual and kinesthetic styles, but that English majors prefer the visual style (Kim, 2007). The present study's results are similar to Kim's; Table 1 shows the result of the descriptive analysis.

Table 1. Descriptive Statistics for College English Majors'Perceptual Learning Styles and Motivation

\begin{tabular}{l|cccc}
\hline & Min. & Max. & M & SD \\
\hline Visual style & 1.00 & 5.00 & 3.70 & 0.56 \\
Auditory style & 1.00 & 5.00 & 3.03 & 0.62 \\
Kinesthetic style & 1.00 & 5.00 & 2.60 & 0.77 \\
Imagination & 1.00 & 5.00 & 2.67 & 0.58 \\
Ideal L2 self & 1.00 & 5.00 & 4.36 & 0.57 \\
Motivated L2 behavior & 1.00 & 5.00 & 3.67 & 0.55 \\
\hline
\end{tabular}

Note. $N=283$

The participants in this study preferred a visual style over both an auditory style and a kinesthetic style. The standard deviation for kinesthetic style was larger than that for visual and auditory styles, showing that kinesthetic style preference varies among individuals more than visual and auditory style preferences do.

The order of preference of perceptual learning styles is consistent with the results previously found for Korean elementary students (Kim, 2009) and secondary students (Kim \& Kim, 2011a). Notable is that visual style preference becomes stronger as students grow up (among elementary students, $M=3.25$; among secondary students, $M=3.30$ for visual style), while auditory and kinesthetic style preference remain similar across all age groups (among elementary students $M=3.10$ for auditory style, $M=2.35$ for kinesthetic style; among secondary students $M=2.95$ for auditory style, $M=2.71$ for kinesthetic style) ${ }^{2}$. This may indicate that as students grow up, they tend to learn more by reading and decoding rather than listening or doing.

\subsection{The relationships between perceptual learning style and the ideal L2 self}

In order to investigate the relationship among the six variables taken up by this study, a Pearson product-moment correlation analysis was performed. The results are summarized in Table 2. In the previous studies among elementary and secondary students, the correlation coefficient between the ideal L2 self and motivated L2 behavior was the

\footnotetext{
2 In Kim and Kim's (2011a) study, six-point Likert scales were used and all the scores presented in this paper were converted into five-point scores. The original scores were $M=3.96$ for visual style, $M=3.54$ for auditory style, and $\mathrm{M}=3.25$ for kinesthetic style.
} 
highest, indicating that learners with a vivid ideal L2 self are most likely to exhibit L2 motivated behavior (Kim, 2009; Kim \& Kim, 2011a). The studies also revealed that visual as well as auditory style preferences were strongly correlated to motivated behavior among the three perceptual styles. In general, the present study also yielded similar results, as summarized in Table 2.

Table 2. Correlations Between College English Majors'Perceptual Learning Styles and Motivation

\begin{tabular}{|c|c|c|c|c|c|c|}
\hline & Visual & Auditory & Kinesthetic & Imagination & Ideal L2 self & $\begin{array}{c}\text { L2 } \\
\text { Motivated } \\
\text { behavior }\end{array}$ \\
\hline \multicolumn{7}{|l|}{ Visual } \\
\hline Auditory & $.187 * *$ & & & & & \\
\hline Kinesthetic & .096 & $.166^{* *}$ & & & & \\
\hline Imagination & $.267 * *$ & $.344 * *$ & $.222 * *$ & & & \\
\hline Ideal L2 Self & $.337 * *$ & $.213 * *$ & .044 & $.294 * *$ & & \\
\hline Motivated behavior & $.338 * *$ & $.344 * *$ & .058 & $.345 * *$ & $.601 * *$ & \\
\hline
\end{tabular}

Note. $N=283,{ }^{* *}$ means significant at the $p<.01$ level, ${ }^{*}$ means significant at the $p<.05$ level

Originally, Al-Shehri (2009) hypothesized that visually oriented learners would have more imagery capacity, thus creating more vivid ideal L2 self and stimulating their motivation. In this study, visual style preference was significantly correlated with imagination, the ideal L2 self, and motivated behavior, as Al-Shehri found. However, not only visual style, but also auditory style also had significant relationships with imagination, the ideal L2 self, and motivated behavior. The result indicates that students preferring auditory style are also likely to imagine and create their ideal L2 self, and stimulate their motivation. The result is consistent with the studies of elementary and secondary school students (Kim, 2009; Kim \& Kim, 2011a).

Kinesthetic style preference was not meaningfully correlated with either the ideal L2 self or motivated L2 behavior. This result is also consistent with the findings among elementary and secondary school students (Kim, 2009; Kim \& Kim, 2011a), and Kim (2009) speculated that in South Korean classroom culture where teacher-centered instruction has been dominant (see Li et al, 2010), students moving around may be stigmatized as troublemakers or as having attention deficits or other difficulties. This suggests that kinesthetic learners are less likely to exhibit motivated behavior than learners preferring other styles, at all levels. 
Tae-Young Kim And Miso Kim Relationships among Perceptual Learning Style, the Ideal L2 Self ...

\subsection{The explanatory power of perceptual styles, imagination, and the ideal L2 self for motivated $\mathrm{L} 2$ behavior}

In order to investigate which variables have explanatory power over motivated L2 behavior, a sequential regression analysis was performed with the three perceptual styles (visual, auditory, kinesthetic), imagination, and the ideal L2 self as independent variables and motivated L2 behavior as the dependent variable (see Table 3). The independent variables were entered in the order of significance derived from the standard regression analysis and correlation coefficients presented above. The variance inflation factor (VIF) ranged from 1.074 to 1.274 and tolerance varied from 0.785 to 0.931 , showing that no multicollinearity existed in this model. The result indicated that the ideal L2 self, imagination, auditory style, and visual style together explained approximately $42.9 \%$ of the total variance. Kinesthetic style had no statistically significant exploratory power over motivated L2 behavior.

Table 3. Sequential Regression Analysis of Variables Explaining Motivated L2 Behavior

\begin{tabular}{|c|c|c|c|c|c|c|c|}
\hline \multirow{2}{*}{ Model } & \multirow{2}{*}{$R$} & \multirow{2}{*}{$R^{2}$} & \multirow{2}{*}{$R^{2}$ Change } & \multirow{2}{*}{$t$} & \multicolumn{2}{|c|}{$\begin{array}{l}\text { Collinearity } \\
\text { Statistics }\end{array}$} & \multirow{2}{*}{$\begin{array}{l}\text { Effect Size } \\
\left(\text { Cohen's f }{ }^{2}\right)\end{array}$} \\
\hline & & & & & Tolerance & VIF & \\
\hline Ideal L2 self & .597 & .356 & .356 & $9.609 * * *$ & .832 & 1.202 & .553 \\
\hline Imagination & .625 & .391 & .035 & $2.436^{*}$ & .785 & 1.274 & .642 \\
\hline Auditory & .648 & .420 & .029 & $3.587 * * *$ & .851 & 1.175 & .724 \\
\hline Visual & .655 & .429 & .009 & $2.102 *$ & .841 & 1.189 & .751 \\
\hline Kinesthetic & .656 & .430 & .001 & -.749 & .931 & 1.074 & .754 \\
\hline
\end{tabular}

Note. $N=283,{ }^{*}$ and $* * *$ mean significant at the $p<.05$ and $p<.001$ level respectively

The ideal L2 self had the highest explanatory power over motivated L2 behavior. Interpreting this finding in conjunction with the correlation coefficient between them $(\mathrm{r}=.601)$, it seems that learners with a more vivid ideal L2 self tend to exhibit higher motivation, and that creating and maintaining a vivid ideal L2 self is thus a key to fostering and maintaining L2 learning motivation. It seems that the ideal L2 self plays a crucial role regardless of learning context or age group, since it was also identified as the first factor predicting motivated L2 behavior among both elementary students (Kim, 2009) and secondary students (Kim \& Kim, 2011a).

Imagination was identified as the second factor predicting motivated L2 behavior. The result supports the claim that vivid and elaborate imagery of future self leads to a more powerful motivation (Dörnyei, 2009). Compared to elementary (Kim, 2009) and secondary students (Kim \& Kim, 2011a), imagination has a significant influence over motivated behavior only among college students. Descriptive statistics shows that the mean of imagination is the lowest $(M=2.67)$ among college students $(M=3.15$ among 
elementary students; $M=3.45^{3}$ among secondary students). The comparison seems to indicate that college students' imagination more directly affects motivated behavior, although they are not likely to use imagination as much as younger students.

Auditory and visual style preference also significantly predicted motivated L2 behavior. Since both variables were also significantly correlated with motivated behavior $(\mathrm{r}=.338$ for visual style, $\mathrm{r}=.344$ for auditory style), it seems that learners preferring auditory and visual styles may have an advantage for the development of motivation. The finding that not only visual but also auditory style preference has explanatory power for motivated L2 behavior is shared with the two previous studies on younger Korean students (Kim, 2009; Kim \& Kim, 2011a). A study on Hong Kong students (Dörnyei \& Chan, 2013) and one on Chinese and Japanese students (Yang \& Kim, 2011) also find that auditory style preference is significantly correlated to the ideal L2 self, suggesting a widely replicable result.

However, among these Korean college English majors, auditory style preference had slightly more explanatory power than visual style preference. The reverse was the case for Korean elementary and secondary students (Kim, 2009; Kim \& Kim, 2011a). This difference may be attributable to the different learning contexts of the studies. In elementary and secondary school, important English tests, such as the College Scholastic Ability Test, are mainly administered in a paper-and-pencil format without a speaking section. Oral language proficiency is often tested as well, but the paper-and-pencil mid-term and final tests make up most of the students' grade. On the other hand, college students studying English are exposed to more oral language than elementary and secondary students, as many of their courses are often delivered in English and they are expected to participate verbally and learn to use spoken English fluently. Jobs for which English is required also often specifically require spoken English. These factors might all contribute to the increase in the predictive power of the auditory style.

The kinesthetic style did not have significant impact upon motivated behavior, across Korean EFL contexts. If kinesthetic learners are not supported, they may be deprived of the chance to raise their motivation and thus of equal educational opportunities (Kim, 2009). Considering that Yang and Kim's (2011) Chinese and Japanese student data, and Dörnyei and Chan's (2013) Hong Kong student data also showed no meaningful relationship between kinesthetic style and motivated behavior, this may not be a problem in the Korean context only.

\subsection{Gender difference in perceptual learning styles and motivational constructs}

Descriptive statistics were calculated and the Mann-Whitney U test was performed to investigate differences in learning style and motivation by gender. Previous studies (Kim, 2009; Kim \& Kim, 2011b) have found significant differences in motivational

\footnotetext{
3 The original score was $M=4.14$, using six-point Likert scale. In the paper, the mean score was converted into five-point scales.
} 
Tae-Young Kim And Miso Kim Relationships among Perceptual Learning Style, the Ideal L2 Self ...

constructs between male and female students in a Korean population. In both studies, female students were more visually oriented than male students, who preferred kinesthetic styles more than female students did. As for the auditory style, it was more preferred by female students than male students in elementary school (Kim, 2009); however, this result was reversed in secondary school (Kim \& Kim, 2011b). The result of college students in the present study, which can be compared to those for elementary and secondary students from the previous studies, are summarized in Table 4.

Table 4. Descriptive Statistics for Variables Based on Gender

\begin{tabular}{ccccccc}
\hline & \multicolumn{3}{c}{ Male } & & \multicolumn{3}{c}{ Female } \\
& $N$ & $M$ & $S D$ & $N$ & $M$ & $S D$ \\
\hline Visual & 63 & 3.59 & .62 & 216 & 3.73 & .53 \\
Auditory & 63 & 2.87 & .69 & 219 & 3.08 & .59 \\
Kinesthetic & 62 & 2.50 & .81 & 220 & 2.63 & .76 \\
Imagination & 62 & 2.62 & .64 & 220 & 2.68 & .57 \\
Ideal L2 Self & 62 & 4.44 & .63 & 219 & 4.34 & .54 \\
L2 Motivated Behavior & 62 & 3.70 & .62 & 217 & 3.67 & .53 \\
\hline
\end{tabular}

The descriptive statistics indicate that female students preferred all three perceptual learning styles more than male students, but that the kinesthetic style was preferred by female students to a greater degree than in previous studies (Kim, 2009; Kim \& Kim, 2011b). In terms of imagination, the ideal L2 self, and motivated behavior, male and female students show similar results. Note that standard deviations for male students are slightly higher than those for female students, for all variables. This may indicate that male students' perceptual learning styles and motivational profiles vary more widely than those of female students. Table 5 shows the gender difference among college students.

Table 5. Mann-Whitney U Test of Perceptual Learning Styles and Motivation

\begin{tabular}{cllllll}
\hline & Visual & Auditory & Kinesthetic & Imagination & $\begin{array}{c}\text { Ideal L2 } \\
\text { self }\end{array}$ & $\begin{array}{c}\text { Motivated } \\
\text { behavior }\end{array}$ \\
\hline $\begin{array}{c}\text { Mann-Whitney } \\
\text { U test }\end{array}$ & 6324.5 & 5890.5 & 6275 & 6062.5 & 5788.0 & 6176 \\
Z-value & -.851 & -1.670 & -.961 & -1.336 & -1.778 & -.983 \\
Significance & .395 & .095 & .337 & .182 & .075 & .325 \\
\hline
\end{tabular}

Note. $N=283$ 
Table 5 shows that no gender difference was found. Thus, all three perceptual learning styles did not vary according to gender, consistent with Kim's (2007) finding on college students. This contrasts the elementary and secondary findings, where male students were more kinesthetically oriented than female students (Kim, 2009; Kim \& Kim, 2011b). Among the younger students, female students exhibited more motivated behavior and a more vivid ideal L2 self (Kim, 2009; Kim \& Kim, 2011b). Kim and Kim (2011b) attribute this to female students' higher preference for visual style, which contributes to the creation of more a vivid ideal L2 self, as Al-Shehri (2009) found. However, the college students in the present study did not exhibit such differences on the ideal L2 self and motivated L2 behavior, consistent with the lack of any difference found in visual style between genders.

\section{Summary AND IMPLiCATIONS}

This study investigated the perceptual learning styles and the ideal L2 self of Korean college students majoring in English-related fields. Previous studies on younger students (Dörnyei \& Chan, 2013; Kim, 2009; Kim \& Kim, 2011a, 2011b, 2014; Yang \& Kim, 2011) have confirmed the positive relation of not only the visual but also the auditory style with the ideal L2 self.

Three research questions were investigated; they can be answered as follows. First, among Korean college English majors, both the visual and auditory styles were linked to the ideal L2 self and motivated L2 behavior, but the kinesthetic style was linked to neither. Motivated L2 behavior was the most strongly correlated factor with the ideal L2 self, followed by imagination and auditory style. Second, the ideal L2 self had most explanatory power of the independent variables for motivated behavior, followed in order by imagination, auditory style, and visual style. Compared to younger students, college students' imagination influenced motivated behavior more strongly, although they used imagination less than younger students. The difference compared to elementary and secondary students, where visual style had more explanatory power than auditory, may be due to the increased importance of oral language at the college learners' level. Kinesthetic style had no statistically significant influence over motivated behavior, suggesting that kinesthetic learners are not given appropriate support at any level of education - a result that has also been reached in other national contexts (Dörnyei \& Chan, 2013; Yang \& Kim, 2011). Third, no significant gender difference was found, unlike the case of elementary and secondary students, where female students in previous studies were better at creating an ideal L2 self and showed more motivated L2 behavior (Kim, 2009; Kim \& Kim, 2011b).

The study has several implications for the instruction of Korean college English majors. First, in general, these students will benefit from the chance to learn by reading charts, diagrams, graphs, and written material, as they preferred the visual style the most. However, courses, activities, or other practices attuned to kinesthetic learners, such as using realia, doing crafts, playing action games, or having frequent breaks, would benefit students who may not receive equal education opportunities, regardless of students' gender. Given the flexibility in course and curriculum design that is possible at the college level, style-based approaches to EFL instruction generally would be more feasible than in elementary or secondary school. 
Tae-Young Kim And Miso Kim Relationships among Perceptual Learning Style, the Ideal L2 Self ...

College learners would benefit more by using vivid imagery to create an ideal L2 self than younger students, as their imagination had more explanatory power over motivated behavior than younger students. Imagery training practices for enhancing the ideal L2 self could be designed in this regard (e.g., Hadfield \& Dörnyei, 2013; Hock, Deshler, \& Shumaker, 2006; Oyserman, 2003). For example, Magid and Chan (2012) reported the results of introducing visualising the ideal L2 self programmes in England and Hong Kong. The college-level students' linguistic self-confidence was enhanced through strengthening their vision of the ideal L2 self, and making their learning goals clearer and more specific. Likewise, imagery training for enhancing the ideal L2 self can be developed in a systematic manner referring to such previous studies.

Two important areas of future research will be the investigation of perceptual styles, imagination, and the ideal L2 self across age groups and in the English as a Second Language (ESL) context. As noted earlier, the students may prefer a visual style as they grow up, and it may have impact on their imagination and the ideal L2 self. A large-scale quantitative longitudinal or cross-sectional study on the students' style preference in different age groups may yield meaningful results. Also, the current paper indicated that both the visual and auditory styles have significant relation with the ideal L2 self and motivated L2 behavior, but the kinesthetic style did not. This tendency holds true for Chinese and Japanese students (Yang \& Kim, 2011) and elementary and secondary school students (Kim, 2009; Kim \& Kim, 2011a). All the studied countries are located in countries where English is not the main means of communication. Given that students in ESL contexts relatively have more opportunities to carry out physical activity using English, kinesthetic style may have a meaningful relationship with the ideal L2 self and motivated behavior in ESL contexts, unlike the findings of this study.

\section{REFERENCES}

Al-Shehri, A. (2009). "Motivation and vision: The relation between the ideal L2 self, imagination and visual style", in Z. Dörnyei and E. Ushioda (Eds.), Motivation, language identity and the L2 self. Bristol, UK: Multilingual Matters, 164-171.

Bang, I.-J. and Chun, S. Y. (2011). "An analysis of high school English curriculum implementation by the high school record rating system", in CNU Journal of Educational Studies, 32, 1: 11-20.

Berkovits, S. (2005). Guided imagery: Successful techniques to improve school performance and self-esteem. Duluth, MN: Whole Person Associates.

Cohen, A., Oxford, R. L. and Chi, J. C. (2002). "Learning style survey: Assessing your own learning styles". Minneapolis, MN: Center for Advanced Research on Language Acquisition. University of Minnesota. Retrieved April 23, 2014, from http://www.carla.umn.edu/ maxsa/documents/learningstylesurvey_MAXSA_IG.pdf

Cohen, A., and Weaver, S. J. (2005). "Styles and strategies-based instruction: A teachers' guide". Minneapolis, MN: Center for Advanced Research on Language Acquisition. University of Minnesota.

Crookes, G. and Schmidt, R. (1991). "Motivation: Reopening the research agenda", in Language Learning, 41: 469-512.

Davis, F. B. (1964). Educational measurements and their interpretation. Belmont, CA: Wadsworth. 
Dörnyei, Z. (2005). The psychology of the language learner: Individual differences in second language acquisition. Mahwah, MJ: Lawrence Erlbaum.

Dörnyei, Z. (2009). "The L2 motivational self system", in Z. Dörnyei and E. Ushioda (Eds.), Motivation, language identity and the L2 self. Bristol, UK: Multilingual Matters, 9-42.

Dörnyei, Z. and Chan, L. (2013). "Motivation and vision: An analysis of future L2 self images, sensory styles, and imagery capacity across two target languages", in Language Learning, 63, 3: 437-462.

Ehrman, M. E. and Leaver, B. L. (1997). "Sorting our global and analytic functions in second language learning", Paper presented at the American Association for Applied Linguistics annual meeting, Orlando, FL, March 8-11, 1997.

Ehrman, M. and Leaver, B. L. (2003). "Cognitive styles in the service of language learning", System, 31, 3: 313-330.

Gardner, R. C. (1985). Social psychology and second language learning: The role of attitudes and motivation. London: Edward Arnold.

Gardner, R. C. (2001). "Integrative motivation and second language acquisition", in Z. Dörnyei and R. Schmidt (Eds.), Motivation and second language acquisition. Honolulu, HI: University of Hawai'i Press, 1-19.

Gardner, R. C. and Lambert, W. E. (1959). "Motivational variables in second language acquisition", in Canadian Journal of Psychology, 13: 266-272.

Gould, D., Damarjian, N. and Greenleaf, C. (2002). "Imagery training for peak performance", in J. L. Van Raalte and B. W. Brewer (Eds.), Exploring sport and exercise psychology (2nd ed.). Washington, DC: American Psychological Association, 49-74.

Hadfield, J. and Dörnyei, Z. (2013). Motivating learning. Harlow, UK: Pearson.

Higgins, E. T. (1987). "Self-discrepancy: A theory relating self and affect", in Psychological Review, 94, 3: 319-340.

Hock, M. F., Deshler, D. D., and Shumaker, J. B. (2006). "Enhancing student motivation through the pursuit of possible selves", in C. Dunkel and J. Kerpelman (Eds.), Possible selves: Theory, research and application. New York: Nova Science, 205-221.

Kim, K. J. (2007). "Predicting English achievement using learning styles of Korean EFL college students", in English Language \& Literature Teaching, 13, 1: 27-46.

Kim, S. A. (2006). "The reality of high school English classes and suggestions to improve them", in English Language Teaching, 18, 4: 77-109.

Kim, T. Y. (2006). "Motivation and attitudes toward foreign language learning as socio-politically mediated constructs: The case of Korean high school students", in The Journal of Asia TEFL, 3, 2: 165-192.

Kim, T. Y. (2009). "Korean elementary school students' perceptual learning style, ideal L2 self, and motivated L2 behavior", in Korean Journal of Language and Linguistics, 9, 3: 461-486.

Kim, T. Y. (2010). "Socio-political influences on EFL motivation and attitudes: Comparative surveys of Korean high school students", in Asia Pacific Education Review, 11, 2: 211-222.

Kim, T. Y., (2012). "The L2 motivational self system of Korean EFL students: Cross-grade survey analysis", in English Teaching, 67, 1: 29-56.

Kim, T. Y. (2017). "EFL learning motivation and influence of private education: Cross-grade survey results", in English Teaching, 72, 3: 25-46.

Kim, T. Y. and Kim, Y. K. (2014). "A structural model for perceptual learning styles, the ideal L2 self, motivated behavior, and Enlgish proficiency", in System, 46: 14-27.

Kim, Y. K. and Kim, T. Y. (2011a). "The effect of Korean secondary school students' perceptual learning styles and ideal L2 self on motivated L2 behavior and English proficiency", in Korean Journal of English Language and Linguistics, 11, 1: 21-42.

Kim, Y. K. and Kim, T. Y. (2011b). "Gender differences in Korean secondary school students' learning styles and L2 motivation", in Foreign Languages Education, 18, 2: 51-71. 
Tae-Young Kim And Miso Kim Relationships among Perceptual Learning Style, the Ideal L2 Self ...

Kosslyn, S. M., Cacioppo, J. T., Davidson, R. J., Hugdahl, K., Lovallo, W. R., Spiegel, D. and Rose, R. (2002). "Bridging psychology and biology: The analysis of individuals in groups", in American Psychologist, 57: 341-351.

Li, G., He, M. F., Tsou, W., Hong, W. P., Curdt-Christiansen, X. and Huong, P. L. (2011). "Teachers and teaching in Sinic education", in Y. Zhao, J. Lei, G. Li, M. F. He, K. Okano, N. Megahed, D. Gamage and H. Ramanathan (Eds.), Handbook of Asian education: A cultural perspective. New York: Routledge, 51-77.

Magid, M. (2012). "The L2 motivational self system from a Chinese perspective: A mixed methods study", in Journal of Applied Linguistics, 6: 69-90.

Magid, M. and Chan, L. (2012). "Motivating English learners by helping them visualise their Ideal L2 Self: Lessons from two motivational programmes", in Innovation in Language Learning and Teaching, 6: 113-125.

Markus, H. R. and Nurius, P. (1986). "Possible selves", American Psychologist, 41: 954-969.

McKay, S. L. (2002). Teaching English as an international language: Rethinking goals and approaches. Oxford, UK: Oxford University Press.

Ministry of Education, Science and Technology. (2009). Chodeunghakgyo gyoyookgwajeong haeseol [The explanation of elementary school curriculum] (Publication Registration No. 11-1341000-000974-14). Seoul, Korea: Ministry of Education, Science and Technology.

Ministry of Education, Science and Technology. (2011). Yeongeogwa gyoyookgwajeong [English curriculum]. Retrieved April 23, 2014, from http://english.kice.re.kr/download/downloadPM. do? savePath=pro\&saveFileNm=edu2009a.pdf

Modell, A. H. (2003). Imagination and the meaningful brain. Cambridge, MA: MIT Press.

Nunnally, J. C. (1967). Psychometric theory (1st ed.). New York: McGraw-Hill.

Oxford, R. L. (1995). "Style analysis survey", in J. Reid (Ed.), Learning styles in the ESL/EFL classroom. Boston, MA: Heinle \& Heinle, 208-215.

Oxford, R. and Shearin, J. (1994). "Language learning motivation: Expanding the theoretical framework", in Modern Language Journal, 78: 12-28.

Oyserman, D. (2003). School-to-jobs facilitators manual (revised ed.). Ann Arbor, MI: University of Michigan.

Papi, M. (2010). "The L2 motivational self system, L2 anxiety, and motivated L2 behavior: A structural equation modeling approach", in System, 38: 467-479.

Park, H. and Lee, H. J. (2013). "L2 motivational selves and WTC in Korean college learners of English: From a structural equation model", in Studies in English Education, 18, 2: 259-284.

Peterson, R. A. (1994). "A meta-analysis of Cronbach's coefficient alpha”, in Journal of Consumer Research, 21, 2: 381-391.

Reid, J. M. (1987). "The learning style preferences of ESL students", in TESOL Quarterly, 21, 1: $87-110$.

Seth, M. J. (2002). Education fever: Society, politics, and the pursuit of schooling in South Korea. Honolulu, HI: University of Hawaii Press.

Taguchi, T., Magid, M. and Papi, M. (2009). "The L2 motivational self system among Japanese, Chinese and Iranian learners of English: A comparative study", in Z. Dörnyei and E. Ushioda (Eds.), Motivation, language identity and the L2 self. Bristol, UK: Multilingual Matters, 66-97.

Ushioda, E. (2010). "Motivation and SLA: Bridging the gap", in EUROSLA Yearbook, 10: 5-20.

Wenger, E. (1998). Communities of practice: Learning, meaning, and identity. Cambridge, UK: Cambridge University Press.

Yang, J. S. and Kim, T. Y. (2011). "The L2 motivational self system and perceptual learning styles of Chinese, Japanese, Korean and Swedish students", in English Teaching, 66, 1: 141-162. 
You, C. J. and Chan, L. (2015). "The dynamics of L2 imagery in future motivational self guides", in Z. Dörnyei, P. MacIntyre and A. Henry (Eds.), Motivational dynamics in language learning. Bristol, UK: Multilingual Matters, 397-418.

You, C. J., Dörnyei, Z. and Csizér, K. (2016). "Motivation, vision, and gender: A survey of learners of English in China", in Language Learning, 66, 1: 94-123.

\section{APPENDIX}

\section{Sample Questionnaire Items}

\section{Visual Style}

- Item 1. I remember homework better if a teacher writes it on the board.

- Item 2. I think about pictures, numbers, or words when I listen to the instructor's explanations.

- Item 3. I underline or highlight important information when I study English.

\section{Auditory Style}

- Item 1. I can understand a speaker well even I do not see him or her.

- Item 2. I easily remember jokes that I hear.

- Item 3. I can tell who a person is just by their voice.

\section{Kinesthetic Style}

- Item 1. I need to take a lot of breaks when I study.

- Item 2. I need to eat something when I read or study.

- Item 3. I can remember better if I move my body (e.g., shaking legs, rolling pencils, moving around).

\section{Imagination}

- Item 1. When I read an interesting story, I imagine its events and characters.

- Item 2. When someone tells me about an interesting place, I imagine what it would be like to be there.

- Item 3. I sometimes drift away into my imagination.

\section{The Ideal L2 Self}

- Item 1. I believe that I can speak English well.

- Item 2. Whenever I think of my future career, I imagine myself being able to speak English.

- Item 3. If my dreams come true, I will speak English fluently in the future.

\section{Motivated L2 Behavior}

- Item 1. I have a very strong desire to learn English.

- Item 2. I can honestly say that I really try to learn English.

- Item 3. Learning English is very important in my life. 